\title{
Large area detector of low-energy gamma radiation
}

\author{
T.A.Nepokupnaya, A.A.Ananenko, A.Yu.Boyarintsev, \\ A.A.Bobovnikov, A.V.Gektin, S.N.Kovalchuk, Yu.D.Onufriyev, \\ V.Yu.Pedash
}

\author{
Institute for Scintillation Materials, STC"Institute for Single Crystals", \\ National Academy of Sciences of Ukraine, \\ 60 Nauky Ave., 61001 Kharkiv, Ukraine
}

\author{
Received April 6, 2017
}

Detectors for registration of low-energy gamma radiation based on plastic scintillator UPS-923A with composite YSO:Ce and CsI:TI layers were developed. Size and concentrations of granules in the composite scintillators were determined experimentally. Additional composite layer in the detector design allowed reducing the gamma radiation registration threshold down to $20 \mathrm{keV}$. It was shown that registration efficiency of $59.5 \mathrm{keV}$ gammaquanta $\left(\mathrm{Am}^{241}\right)$ of the detector with YSO:Ce composite layer was 4 times higher than that of UPS-923A. The detector with CsI:TI composite layer had 1.5 times higher sensitivity and almost 2 times lower minimum detectable activity in comparison to UPS-923A under $\mathrm{Am}^{241}$ irradiation.

Keywords: low-energy gamma radiation, composite scintillator, MDA, detection sensitivity.

Получены детекторы для регистрации низкоэнергетического гамма-излучения на основе сцинтилляционной пластмассы UPS-923A с композиционным слоем YSO:Cе и Csl:TI. Подобраны размеры и концентрация гранул в композиционных сцинтилляторах. Использование композиционного слоя в конструкции детектора позволяет снизить порог регистрации гамма-квантов до 20 кэВ. Показано, что эффективность регистрации гамма-квантов с энергией 59,5 кәВ $\left(\mathrm{Am}^{241}\right)$ для детектора с композиционным слоем YSO:Ce в 4 раза выше, чем для UPS-923A. Детектор с композиционным слоем CsI:TI имеет чувствительность в 1,5 раза выше, а МДА почти в 2 раза ниже по сравнению с UPS-923A при облучении $\mathrm{Am}^{241}$.

Детектор низькоенергетичного гамма випромінення великої площі. T.A.Hепокynна, А.ААнаненко, А.Ю.Бояринцев, А.А.Бобовніков, А.В.Гектин, С.Н.Ковальчук, Ю.Д.Онуфрієв, В.Ю.Педаш

Отримано детектори для реєстрації низькоенергетичного гамма випромінення на основі сцинтиляційної пластмаси UPS-923A з композиційним шаром YSO:Ce та Csl:TI. Підібрано розміри та концентрацію гранул у композиційних сцинтиляторах. Використання композиційного шару у конструкції детектора дозволяє знизити поріг реєстрації гамма-квантів до 20 кэВ. Показано, що ефективність реєстрації гамма-квантів 3 енергією 59,5 кәВ $\left(\mathrm{Am}^{241}\right)$ для детектора з композиційним шаром YSO:Cе у 4 рази вища, ніж для UPS-923A. Детектор з композиційним шаром Csl:TI має чутливість у 1,5 рази вищу, а МДА у 2 рази нижчу у порівнянні з UPS-923A при опроміненні $\mathrm{Am}^{241}$. 


\section{Introduction}

The main devices for detection of nuclear materials are radiation portal monitors with neutron and gamma detectors [1]. The common materials for gamma radiation detection are $\mathrm{Nal}(\mathrm{TI})$ and plastic scintillators based on polystyrene or polyvinyl toluene. $\mathrm{Nal}(\mathrm{TI})$ detectors effectively register gamma radiation in $0.06-3.0 \mathrm{MeV}$ energy range but they are expensive. The use of cheap plastic scintillators allows covering the large areas subjected to radiometric control. However, this material has low light output. Consequently, the minimum detectable activity (MDA) for plastic scintillators in the low energy region is significantly higher than the MDA in the medium and high energies range.

In this work the way to increase MDA for plastic scintillator in the low energy range is proposed. The solution is the detector that consists of plastic and composite scintillators. The operating principle of such detector is based on absorption of gamma rays with energies of $20 \mathrm{keV}$ and higher in composite scintillator with emission of light with a wavelength for which the plastic scintillator is a transparent media. At the same time, the high-energy radiation passes through small thickness of the composite layer and it is registered directly by the plastic scintillator.

The composite scintillators usage in the proposed detector allows obtaining the costefficient large size detectors from commercially available materials.

\section{Experimental}

In this work three detectors based on plastic scintillators UPS-923A with an additional YSO:Ce or CsI:TI composite layer were fabricated and tested. YSO:Ce is a the non hygroscopic material with a sufficiently high light output [2]. CsI:TI is the high light output commercially available scintillator [3]. This material is slightly hygroscopic and requires encapsulation to increase the lifetime.

The composition and dimensions of the composite scintillators, as well as the di- mensions of the plastic scintillator, are shown in Table 1. The detectors manufacturing comprises the following steps:

- manufacturing of UPS-923A plate with the required size, the reflector forming;

- coating of UPS-923A with YSO:Ce or CsI:TI composite layer, the detector encapsulation.

All UPS-923A surfaces were polished. The method of YSO:Ce and CsI:TI composite scintillators fabrication was the same as described in [4]. Scintillation granules of 63$100 \mu \mathrm{m}$ were used for the composite layer fabrication. Optically transparent chemically inert polysiloxane was used as a binder [5]. The granules content in the composite layer was $75 \mathrm{wt} . \%$ and $50 \mathrm{wt} \%$. The composite layer thickness of $0.5 \mathrm{~mm}$ was selected experimentally. Diffuse reflector was used to improve the light collection in the detector. During the manufacturing the scintillation characteristics of the UPS-923A plates and detectors based on UPS-923A with the composite layer were measured. Amplitude spectra of the detectors were recorded using AMA-03F multichannel analyzer (Tensor, Russia). ${ }^{137} \mathrm{Cs}(33 \mathrm{keV})$ and ${ }^{241} \mathrm{Am}$ $(59.5 \mathrm{keV})$ were used as gamma sources.

During the counting rate measurements of UPS-923A $\left(20 \times 60 \times 100 \mathrm{~mm}^{3}\right)$, an entrance window with dimension $20 \times 60 \mathrm{~mm}$ was coupled to R1924A Hamamatsu PMT ( $\left.\varnothing 1^{\prime \prime}\right)$. The same parameters for UPS-923A $\left(50 \times 250 \times 1000 \mathrm{~mm}^{3}\right)$ were measured with R1306 Hamamatsu PMT $\left(\varnothing 2^{\prime \prime}\right)$ coupled to $50 \times 250 \mathrm{~mm}$ entrance window of the scintillator. The side of the scintillator with maximum area was selected for irradiation. The gamma source was located in such a way that the scintillator surface was evenly irradiated.

The count rate measurement of UPS923A with YSO:Ce or CsI:TI composite layer was made similarly. Gamma source was placed on the side covered with the composite scintillator.

Minimal detective activity of $1000 \times 250 \times 50 \mathrm{~mm}^{3}$ UPS- $923 \mathrm{~A}$ and No. $3 \mathrm{de}-$

Table 1. Composition and dimensions of the composite and plastic scintillators

\begin{tabular}{||c|c|c|c|c||}
\hline $\begin{array}{c}\text { Detector } \\
\text { number }\end{array}$ & $\begin{array}{c}\text { Composite layer } \\
\text { material }\end{array}$ & $\begin{array}{c}\text { Scintillator content , } \\
\text { wt. } \%\end{array}$ & $\begin{array}{c}\text { Composite layer } \\
\text { dimensions, } \mathrm{mm}^{3}\end{array}$ & $\begin{array}{c}\text { UPS-923A } \\
\text { dimensions, } \mathrm{mm}^{3}\end{array}$ \\
\hline 1 & YSO:Ce & 75 & $100 \times 60 \times 0.5$ & $100 \times 60 \times 25$ \\
\hline 2 & YSO:Ce & 50 & $100 \times 60 \times 0.5$ & $100 \times 60 \times 25$ \\
\hline 3 & CsI:TI & 50 & $1000 \times 250 \times 0.5$ & $1000 \times 250 \times 50$ \\
\hline
\end{tabular}


Table 2. Count rate of plastic scintillator UPS-923A and detectors based on UPS923A with YSO:Ce composite layer.

\begin{tabular}{|c|c|c||}
\hline Scintillator & $\begin{array}{c}\text { Granule } \\
\text { concentration of } \\
\text { YSO:Ce, wt. } \%\end{array}$ & $\begin{array}{c}\text { Count } \\
\text { rate, pps }\end{array}$ \\
\hline UPS-923A & - & 24 \\
\hline Detector No.1 & 75 & 3.8 \\
\hline Detector No.2 & 50 & 105 \\
\hline
\end{tabular}

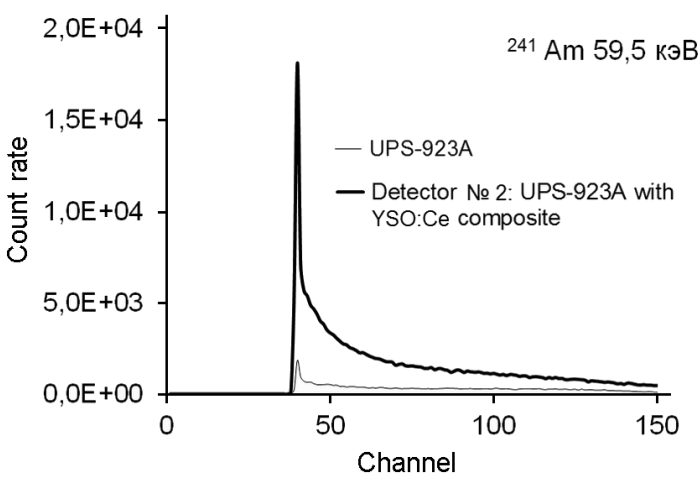

Fig. 1. Amplitude spectra for detectors based on UPS-923A with YSO:Ce composite layer and for UPS-923A plate under ${ }^{241} \mathrm{Am}$ $(59.5 \mathrm{keV})$ irradiation.

tector with CsI(TI) composite layer under irradiation with ${ }^{137} \mathrm{Cs}$ (33 keV line) and ${ }^{241} \mathrm{Am}(59.5 \mathrm{keV}$ line) was calculated using the following expression:

$$
M D A=\frac{2}{\eta} \sqrt{\frac{N_{f}}{t}},
$$

where $\eta$ - detection sensitivity, $N_{f}$ - background count rate, $t-$ acquisition time. Detection sensitivity $\eta$ was calculated as:

$$
\eta=\frac{N-N_{f}}{A}
$$

where $N$ - count rate under gamma irradiation, $A$ - activity of radiation source.

\section{Results and discussion}

Count rate of detectors No.1, 2 with YSO:Ce composite layer was compared with he one of $20 \times 60 \times 100 \mathrm{~mm}^{3}$ UPS-923A under irradiation with ${ }^{241} \mathrm{Am}$ source. The registration threshold during the measurements was set $20 \mathrm{keV}$. Results are shown in Table 2 .

Amplitude spectra of detectors No.2 and UPS-923A under ${ }^{241} \mathrm{Am}$ irradiation are shown in Fig. 1.

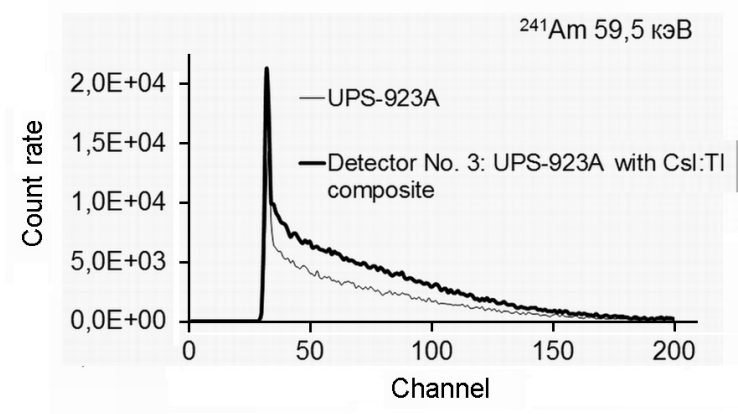

Fig. 2. Amplitude spectra for detector based on UPS-923A with Csl:TI composite layer and for UPS-923A plate under ${ }^{137} \mathrm{Cs}$ (33 keV) irradiation.

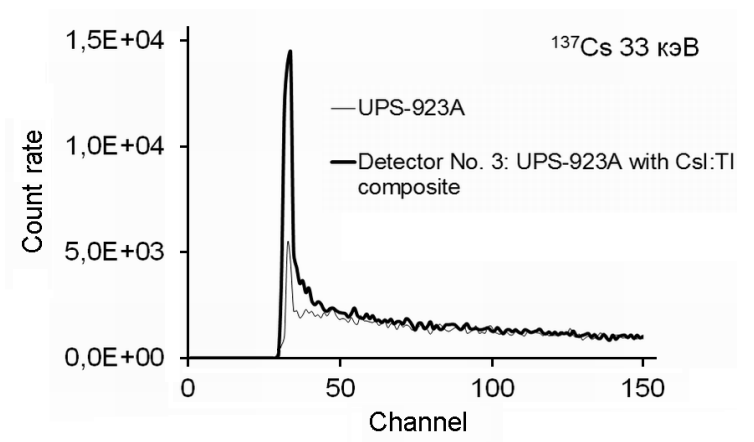

Fig. 3. Amplitude spectra for detector based on UPS-923A with Csl:TI composite layer and for UPS-923A plate under irradiation ${ }^{241} \mathrm{Am}(59.5 \mathrm{keV})$.

As one can conclude from the obtained results the count rate of the detector with 50 wt. \% YSO:Ce composite layer is 4 times higher compared to the count rate of the same size UPS-923A.

Increase in the granules content up to 75 wt. \% leads to significant decrease in the transparency of the composite layer and, as a consequence, to a sharp drop in the light output of the detector.

Detection sensitivity and MDA were determined for detector No.3 with CsI(TI) composite layer under irradiation with ${ }^{137} \mathrm{Cs}$ and ${ }^{241} \mathrm{Am}$. The registration threshold during the measurements was set at $20 \mathrm{keV}$. Results are shown in Table 3. Amplitude spectra for detectors No.3 and UPS-923A under ${ }^{241} \mathrm{Am}$ irradiation are shown in Fig. 2 and 3 , respectively. It should be noted, that during the measurements the background count rate of the detector with composite layer was higher than one of UPS923A. However, after detector flashing for $60 \mathrm{~min}$, the background count rate was re- 
Table 3. Detection sensitivity $\eta$ and MDA of UPS-923A plastic scintillator and of the detector based on UPS-923A with CsI(TI) composite layer

\begin{tabular}{|c|c|c|c|c|c|c|c|}
\hline \multirow[t]{2}{*}{ Scintillator } & \multicolumn{2}{|c|}{ Count rate, pps } & \multirow{2}{*}{$\begin{array}{c}\text { Background } \\
\text { count rate, } \\
\text { pps }\end{array}$} & \multicolumn{2}{|c|}{$\eta, \mathrm{pps} \cdot \mathrm{kBq}$} & \multicolumn{2}{|c|}{ MDA, pps $\cdot k B q$} \\
\hline & ${ }^{241} \mathrm{Am}$ & ${ }^{137} \mathrm{Cs}$ & & ${ }^{241} \mathrm{Am}$ & ${ }^{137} \mathrm{Cs}$ & ${ }^{241} \mathrm{Am}$ & ${ }^{137} \mathrm{Cs}$ \\
\hline UPS-923A & 6067 & 6576 & 4980 & 11.7 & 35 & 17.1 & 5,7 \\
\hline Detector No.3 & 6652 & 6539 & 4883 & 19 & 36.5 & 10.4 & 5.4 \\
\hline
\end{tabular}

duced to the level for the plastic scintillator. Probably, it is connected with the method of preparation of scintillation granules. Specifically, with introducing the stress into crystal lattice of $\mathrm{CsI}(\mathrm{TI})$ as a consequence there is mechanical crushing of a the single crystal. As it can be seen from the measurement results the detection sensitivity of the detector with Csl:Tl composite layer is 1.5 times higher and MDA is almost 2 times lower than the same parameters of the standard UPS-923A detector under ${ }^{241} \mathrm{Am}$ irradiation.

\section{Conclusions}

The detectors based on plastic scintillator with YSO:Ce and Csl:TI composite layer for registration of low-energy gamma radiation were manufactured.

The size and concentration of scintillation granules in the composite scintillator, which allows increasing the detection efficiency of the low energy gamma radiation were determined. The use of the composite layer in the detector design allows reducing the registration threshold of gamma radiation down to $20 \mathrm{keV}$.

It was shown that registration efficiency of $59.5 \mathrm{keV}$ gamma-quanta (from ${ }^{241} \mathrm{Am}$ ) for the detector with YSO:Ce composite layer is 4 times higher than that for UPS-923A. Sensitivity of the detector with Csl:TI composite layer is 1.5 times higher and MDA is almost 2 times lower in comparison to UPS923A when irradiated with ${ }^{241} \mathrm{Am}$.

\section{References}

1. O.E.Bogomolova, B.V.Grynyov, A.I.Ivanov et al., Inform. Proc. Syst., 9, 204 (2011).

2. P.A.Cutler, C.L.Melcher, A.Spurrier et al., IEEE Trans. Nucl. Sci., 56, 915 (2009).

3. I.Holl, E.Lorenz, G.Mageras, IEEE Trans. Nucl.Sci., 35, 105 (1988).

4. Ukraine Patent 111455 (2016).

5. A.Yu.Boyarintsev, N.Z.Galunov, N.L.Karavaeva et al., Functional Materials, 20, 471 (2013). 